\title{
Effects of exogenous fibrolytic and amylolytic enzymes on ruminal fermentation and performance of mid-lactation dairy cows
}

\author{
Elissandra M. C. Zilio, ${ }^{1}$ Tiago A. Del Valle, ${ }^{1}$ Lucas G. Ghizzi, ${ }^{1}$ Caio S. Takiya, ${ }^{2}$ Mauro S. S. Dias, ${ }^{1}$ \\ Alanne T. Nunes, ${ }^{1}$ Guilherme G. Silva, ${ }^{1}$ and Francisco P. Rennó ${ }^{1 *}$ \\ ${ }^{1}$ Department of Animal Nutrition and Animal Production, University of São Paulo, Pirassununga, Brazil 13635-900 \\ ${ }^{2}$ Department of Animal Sciences and Industry, Kansas State University, Manhattan 66506
}

\begin{abstract}
Lactation diets are composed mostly of carbohydrates that are not fully fermented by rumen microbes. The aim of this study was to evaluate exogenous fibrolytic (Fibrozyme, Alltech Inc., Nicholasville, KY) and amylolytic (Amaize, Alltech Inc.) enzymes on nutrient intake, sorting index, total-tract apparent digestibility, ruminal fermentation, nitrogen utilization, milk yield, and composition of dairy cows in mid-lactation. Thirtytwo multiparous Holstein cows $(181 \pm 35 \mathrm{~d}$ in milk, $571 \pm 72.7 \mathrm{~kg}$ of body weight, and $29.6 \pm 5.24 \mathrm{~kg} / \mathrm{d}$ of milk yield at the start of experiment) were blocked according to milk yield and randomly allocated to treatments in a $4 \times 4$ Latin square design. Treatments were (1) control, basal diet without exogenous enzymes; (2) fibrolytic enzyme (FIB), dietary supplementation of Fibrozyme at $12 \mathrm{~g} / \mathrm{d}$ (51 IU of xylanase activity/ $\mathrm{kg}$ of diet dry matter); (3) amylolytic enzyme (AMY), dietary supplementation of Amaize at $8 \mathrm{~g} / \mathrm{d}$ (203 fungal amylase units $/ \mathrm{kg}$ of diet dry matter); and (4) both fibrolytic and amylolytic enzymes (FIB+AMY) added at the same dose of the individual treatments. Enzyme products were added to the concentrate during its preparation (once a week). The supply of FIB and AMY had no effect on nutrient intake and digestibility. However, an interaction effect was observed on sorting index of feed particle size between 8 and 19 $\mathrm{mm}$. Amylolytic enzyme increased the sorting for feed particles between 8 and $19 \mathrm{~mm}$, only when fed without FIB. In addition, AMY decreased the sorting for feed with particle size greater than $19 \mathrm{~mm}$. An interaction effect was observed between FIB and AMY for ruminal butyrate concentration and $\mathrm{N}$ excretion. Amylolytic enzyme increased ruminal butyrate concentration in
\end{abstract}

Received April 19, 2018

Accepted September 9, 2018.

*Corresponding author: francisco.renno@usp.br cows treated with FIB. Further, FIB decreased milk protein production and feed efficiency only in cows not fed AMY. Amylolytic enzyme reduced urinary N excretion. Exogenous enzymes had no effect on milk production and composition of dairy cows. This study lacks evidence that fibrolytic and amylolytic enzymes can affect nutrient digestibility, ruminal fermentation, and performance of mid-lactation cows.

Key words: $\alpha$-amylase, enzymatic product, fiber, starch

\section{INTRODUCTION}

Ruminants use energy from structural polysaccharide digestion to produce meat and milk, which have a relatively high nutritive value. Chemical, physical, and biological methods are used to neutralize antinutritional factors and improve feed digestibility in livestock feedstuffs (Sujani and Seresinhe, 2015). The dietary supplementation with exogenous enzymes has attracted attention of researchers because it is a biological treatment method and generally recognized as safe. Exogenous enzymes have been used to improve nutrient utilization in several species, especially in the poultry and swine industries. Although experiments evaluating dietary enzymes for ruminants have been reported since 1960 (Burroughs et al., 1960), the feasible utilization of dietary enzymes have started in this century, largely due to a decrease in fermentation/generation costs and new technologies to produce purified and more consistent enzyme preparations. A series of experiments to expand the knowledge of fibrolytic (Beauchemin and Rode, 1996; Beauchemin et al., 2003; Arriola et al., 2017) and amylolytic (Chen et al., 1995; DiLorenzo et al., 2011; McCarthy et al., 2013) enzyme activities in the rumen has been performed in the last decade. These studies provided evidences that enzymes are somewhat resistant to rumen degradation and potentially increase the rate of ruminal carbohydrate degradation.

Xylanases and cellulases are the most used fibrolytic enzymes in ruminant diets and have demonstrated 
positive effects on total-tract digestibility of DM and NDF in dairy cows (Arriola et al., 2017). Improvements in fiber digestibility suggest that ruminal endogenous enzyme secretion is limited/inefficient (Beauchemin et al., 2003). Oba and Allen (1999) reported that 1-unit increase in forage NDF digestibility was associated with an increase of 0.17 and $0.25 \mathrm{~kg} / \mathrm{d}$ in DMI and $4 \%$ FCM, respectively. Fibrolytic enzymes have increased milk yield, whereas the variation in response has been attributed to different sources and doses of exogenous enzymes (Arriola et al., 2017). Amylolytic enzymes have been used in ruminant diets to increase ruminal starch digestibility (Nozière et al., 2014) and milk production (Tricarico et al., 2005), but the most reported effects of amylolytic enzymes are increased NDF digestibility in lactating cows (Klingerman et al., 2009; Gencoglu et al., 2010; Weiss et al., 2011) and improved energy balance in transition dairy cows (DeFrain et al., 2005). Tricarico et al. (2008) proposed the cross-feeding mechanism to explain the improvements in digestibility of nutrients not targeted by enzymes: exogenous enzymes hydrolyze complex carbohydrates into different products (malto-, cello-, and xylo-oligosaccharides), which supports growth of fibrolytic microorganisms. Thus, a synergistic effect between fibrolytic and amylolytic enzymes could be expected.

The combination of fibrolytic and amylolytic enzymes has been little explored in dairy cow nutrition, and to the best of our knowledge, only Hristov et al. (2008) evaluated the effects of dietary supplementation of enzyme products with both xylanase and $\alpha$-amylase activity on nutrient digestibility in dairy cows. However, these authors did not evaluate animal performance and enzymes were provided intraruminally, using only 4 animals. As Arriola et al. (2017) reported no effect of DIM on response of dairy cows to fibrolytic enzymes and the most positive amylolytic enzyme effect on performance of cows was found in mid-lactation dairy cows (Tricarico et al., 2005; Andreazzi et al., 2018), cows in this lactation phase were chosen and the trial was performed with a greater number of experimental units to enhance statistical power.

In this context, we hypothesized that dietary supplementation with exogenous enzymes would increase nutrient digestibility (especially of NDF) and ruminal total VFA concentration, and improve milk production and composition of dairy cows. The aim of this study was to evaluate the effects of both fibrolytic and amylolytic enzymes on intake and apparent total-tract digestibility of nutrients, sorting index, ruminal fermentation, milk yield and composition, $\mathrm{N}$ utilization, and microbial protein synthesis of mid-lactation cows.

\section{MATERIALS AND METHODS}

The experiment was conducted at the Dairy Cattle Research Laboratory of the Department of Animal Nutrition and Animal Production of the School of Veterinary Medicine and Animal Sciences, Pirassununga, São Paulo, Brazil. Experimental procedures were carried out under the approval of the Ethics Committee of the School of Veterinary Medicine and Animal Sciences of University of São Paulo (approval number: 2388290517).

\section{Animals and Treatments}

Thirty-two multiparous Holstein cows $(181 \pm 35.3$ DIM, $571 \pm 72.7 \mathrm{~kg}$ of BW, and $29.6 \pm 5.24 \mathrm{~kg} / \mathrm{d}$ of milk yield at the start of experiment; mean $\pm \mathrm{SD}$ ) were enrolled to the experiment. Cows were housed in a barn containing individual pens $\left(17.5 \mathrm{~m}^{2}\right.$ area $)$, with sand bedding, feed bunks, and free access to water. Animals were distributed into 8 blocks according to their milk production, DIM, ruminal cannula presence, and BW. Animals within blocks were randomly allocated to a sequence of treatments in a $4 \times 4$ Latin square experimental design. Eight rumen-cannulated cows (within those 32 cows) were used to evaluate ruminal fermentation. Each experimental period lasted $21 \mathrm{~d}$, where the first $14 \mathrm{~d}$ was allowed for treatment adaptation (Machado et al., 2016) and the following $7 \mathrm{~d}$ was used for data sampling.

Experimental diets were formulated according to the NRC (2001; Table 1) recommendations to meet the nutrient requirements for a cow with $580 \mathrm{~kg}$ of BW, yielding $30 \mathrm{~kg} / \mathrm{d}$ of milk, and 180 DIM. Treatments were obtained from a $2 \times 2$ factorial arrangement and cows were assigned to the following treatments: (1) control, basal diet without exogenous enzymes; (2) fibrolytic enzyme (FIB), dietary supplementation of Fibrozyme (Alltech Inc., Nicholasville, KY) at 12 g/d (51 IU of xylanase activity/kg of diet DM); (3) amylolytic enzyme (AMY), dietary supplementation of Amaize (Alltech Inc.) at $8 \mathrm{~g} / \mathrm{d}[203$ fungal amylase units $(\mathbf{F A U}) / \mathrm{kg}$ of diet $\mathrm{DM}]$; and (4) both fibrolytic and amylolytic enzymes (FIB+AMY) added at the same dose of the individual treatments. Enzyme products were added to the concentrate during its preparation (once a week) at a rate of $1.00 \mathrm{~g} / \mathrm{kg}$ of DM of concentrate for FIB and $0.667 \mathrm{~g} / \mathrm{kg}$ of DM of concentrate for AMY. According to the manufacturer, Fibrozyme is an extract from Trichoderma longibrachiatum fermentation (a dry mixture of inactive yeast, dry brewery yeast, and yucca extract) with a minimum of $100 \mathrm{IU}$ of xylanase activity 
per gram of product. Amaize consists of an Aspergillus oryzae culture extract with known $\alpha$-amylase activity (600 FAU/g of product). One FAU is defined as the amount of enzyme that degrades $1 \mathrm{~g}$ of dextrinized soluble starch per $\mathrm{h}$ at $30^{\circ} \mathrm{C}$ and $\mathrm{pH}$ of 4.8 (Food Chemicals Codex, 1996).

Before the start of the experiment, samples of diet ingredients were shipped to Alltech Inc., and the company performed a dual-flow continuous in vitro trial to determine the appropriate doses of enzymes for the diet used in the current study.

Table 1. Ingredients, chemical composition, and particle size distribution of experimental diet

\begin{tabular}{lc}
\hline Item & Value \\
\hline Ingredient (g/kg of DM) & \\
Corn silage & 480 \\
Ground corn & 212 \\
Soybean meal $(48 \% \mathrm{CP})$ & 149 \\
Citrus pulp & 67.3 \\
Whole raw soybean ${ }^{2}$ & 60.4 \\
Mineral premix & 12.6 \\
Calcium bicarbonate & 8.55 \\
Urea & 3.68 \\
Limestone & 3.09 \\
Salt & 3.31 \\
Chemical composition $(\mathrm{g} / \mathrm{kg}$ of DM) & \\
DM (g/kg as fed) & 524 \\
OM & 928 \\
NFC & 408 \\
NDF & 329 \\
Starch & 285 \\
ADF & 235 \\
CP & 168 \\
Indigestible NDF & 120 \\
Ether extract & 38.0 \\
Lignin & 37.7 \\
Neutral detergent insoluble protein & 19.2 \\
Acid detergent insoluble protein & 16.0 \\
Total digestible nutrient $(1 \times)^{5}$ & 728 \\
NE $(3 \times)^{6}$ (Mcal/kg of DM) & 1.67 \\
Particle size distribution $(\mathrm{g} / \mathrm{kg}$ as fed) & 85.8 \\
>19 mm & 366 \\
8-4 mm 8 & 182 \\
$<4$ mm & 334 \\
\hline
\end{tabular}

${ }^{1}$ Chemical composition (DM basis): $36.4 \%$ DM, $7.8 \%$ CP, $51 \%$ NDF, and $21.6 \%$ starch.

${ }^{2}$ Chemical composition (DM basis): $91.5 \%$ DM, 37.9\% CP, $25.6 \%$ NDF, $9.75 \%$ starch, and $21.7 \%$ ether extract.

${ }^{3}$ Each kilogram contained $205 \mathrm{~g}$ of $\mathrm{Ca}, 60 \mathrm{~g}$ of $\mathrm{P}, 35 \mathrm{~g}$ of $\mathrm{K}, 70 \mathrm{~g}$ of $\mathrm{Na}, 20 \mathrm{~g}$ of S, $20 \mathrm{~g}$ of $\mathrm{Mg}, 2,500 \mathrm{mg}$ of $\mathrm{Zn} ; 1,600 \mathrm{mg}$ of $\mathrm{Mn}, 700 \mathrm{mg}$ of $\mathrm{Cu}, 700 \mathrm{mg}$ of $\mathrm{Fe}, 40 \mathrm{mg}$ of I, $19 \mathrm{mg}$ of Se, $10 \mathrm{mg}$ of $\mathrm{Cr}, 200,000 \mathrm{IU}$ of vitamin $\mathrm{A}, 50,000 \mathrm{IU}$ of vitamin $\mathrm{D}$, and $1,500 \mathrm{IU}$ of vitamin $\mathrm{E}$.

${ }^{4} \mathrm{NFC}=1,000-[(\mathrm{CP}-$ neutral detergent insoluble protein $)+$ ether extract + ash $+\mathrm{NDF}$ ] according to Hall (2000); all values expressed as grams per kilogram of DM.

${ }^{5}$ Estimated at maintenance level of feed intake according to NRC (2001).

${ }^{6}$ Estimated at three times maintenance level according to NRC (2001).

\section{Sampling and Chemical Analysis}

Cows were fed twice daily (0800 and $1300 \mathrm{~h}$ ), after the forage and concentrate were hand mixed in each feed bunk. Refusals from each cow were weighed daily to maintain orts between 5 and $10 \%$ (on an as-fed basis) of feed supplied on the previous day. During the sampling period, corn silage and ort samples were collected daily and pooled to form a composite sample per cow per period for chemical analysis. Concentrate ingredients were collected weekly during the concentrate mixing at the feed mill. Samples of TMR and orts from each cow were collected on d 16 and 17 of each period and assessed for particle size distribution using a particle separator system (Penn State Particle Separator, Nasco, Fort Atkinson, WI). Sorting index was calculated according to Silveira et al. (2007).

From d 17 to 19 of each experimental period, fecal and urine samples were collected every $9 \mathrm{~h}$ (starting at $0600 \mathrm{~h}$ on $\mathrm{d}$ 17) for estimation of total-tract nutrient digestibility, microbial protein synthesis, and nitrogen balance. After each sampling, fecal samples (100 g) were frozen and at the end of each experimental period, samples from each cow were thawed and pooled on a wet basis. Samples of feeds, orts, and feces were dried at $60^{\circ} \mathrm{C}$ in a forced-air oven for $72 \mathrm{~h}$ and ground in a Wiley mill (MA340, Marconi, Piracicaba, Brazil) through a 2-mm or a 1-mm sieve. Samples of feeds, orts, and feces (processed at $1 \mathrm{~mm}$ ) were analyzed for DM (method 930.15; AOAC International, 2000), $\mathrm{CP}(\mathrm{N} \times 6.25$; Kjeldahl method 984.13; AOAC International, 2000), ether extract (EE; method 920.39; AOAC International, 2000), ADF, and lignin (method 973.18; AOAC International, 2000), ash (method 942.05; AOAC International, 2000), and NDF using Q-amylase (Undersander et al., 1992) and without addition of sodium sulfite (TE-149 fiber analyzer, Tecnal Laboratory Equipment Inc., Piracicaba, Brazil). Starch content was determined by enzymatic degradation (Termamyl Amyloglucosidase AMG 300L, Novozymes, Bagsvaerd, Denmark) and absorbances were measured in a spectrophotometer (SBA 200, CELM) as described by Hendrix (1993).

Indigestible neutral detergent fiber (iNDF) was used as an internal marker to estimate daily DM fecal excretion. Samples of feeds, orts, and feces (ground at 2 $\mathrm{mm}$ ) were placed into bags of nonwoven fabric tissue $\left(5 \times 5 \mathrm{~cm}\right.$ at $100 \mathrm{~g}$ of $\mathrm{DM} / \mathrm{m}^{2}$; Casali et al., 2008) and incubated for $288 \mathrm{~h}$ in the rumen of 2 Holstein cows according to Huhtanen et al. (1994). After the incubation period, samples were washed in running tap water and analyzed for NDF content, as described earlier. Total 
apparent digestibility was calculated based on nutrient intake and nutrient excretion.

Ruminal digesta was collected ( 5 different sites within the rumen) from cows with ruminal cannula $(\mathrm{n}=8)$ on d 20 of each experimental period, before the morning feeding (time 0 ), and $2,4,6,8,10,12,14$, and $16 \mathrm{~h}$ after. Digesta was squeezed into 4 cheesecloth layers to extract ruminal fluid and $\mathrm{pH}$ was measured using a digital potentiometer (MB-10, Marte Científica, Santa Rita do Sapucaí, Brazil). For $\mathrm{NH}_{3}-\mathrm{N}$ concentration, aliquots of ruminal fluid $(2 \mathrm{~mL})$ were mixed with sulfuric acid $(1 \mathrm{~mL}$ at $1 \mathrm{~N})$ and analyzed by the colorimetric phenolhypochlorite method (Broderick and Kang-Meznarich, 1980). Ruminal fluid was also mixed with formic acid (at a ratio of 4 to 1 ) for VFA analysis. Volatile fatty acids were determined according to Ferreira et al. (2018), using a gas chromatograph (Agilent 7890A) equipped with flame ionization detector (7683B) and a fusedsilica capillary column (J \& W 19091 F-112, Agilent Technologies, Santa Clara, CA), $25 \mathrm{~m}$ length and 320 $\mu \mathrm{m}$ internal diameter, containing $0.20 \mu M$ cyanopropyl polysiloxane. The total chromatographic run time was $16.5 \mathrm{~min}$, divided into 3 heating cycles, as follows: $80^{\circ} \mathrm{C}$ $(1 \mathrm{~min}), 120^{\circ} \mathrm{C}\left(20^{\circ} \mathrm{C} / \mathrm{min}\right.$ for $\left.3 \mathrm{~min}\right)$, and $205^{\circ} \mathrm{C}\left(10^{\circ} \mathrm{C} /\right.$ min for $2 \mathrm{~min}$ ). Hydrogen was used as the carrier gas at a flow rate of $1.0 \mathrm{~mL} / \mathrm{min}$, and the temperature of the injector and detector was $260^{\circ} \mathrm{C}$. Nitrogen gas was used as the "make-up" gas at a rate of $30 \mathrm{~mL} / \mathrm{min}$. Volatile acid peaks and concentrations were determined using ChemStation software (Agilent Technologies).

Cows were milked twice daily, at 0600 and $1600 \mathrm{~h}$, and milk production was electronically recorded (Alpro, DeLaval, Tumba, Sweden). Milk samples were taken from every milking from d 16 to d 18 of each experimental period and analyzed for fat, lactose, and crude protein concentration using an infrared milk analyzer (Lactoscan, Entelbra, São Paulo, Brazil). Milk samples $(20 \mathrm{~mL})$ were deproteinized according to Broderick and Clayton (1997) and analyzed for urea concentration using commercial kits (Bioclin, Belo Horizonte, Brazil) in a semi-automatic analyzer (SBA 200, CELM). Milk yields were corrected for $3.5 \%$ fat content according to Sklan et al. (1992).

Nitrogen balance was calculated as the difference between $\mathrm{N}$ intake and the sum of fecal, urinary, and milk N. Nitrogen excreted in milk was calculated based on milk CP content (6.38 as conversion factor). Fecal excretion of $\mathrm{N}$ was calculated multiplying $\mathrm{N}$ content in feces $(\mathrm{g} / \mathrm{kg})$ by the estimated DM fecal excretion $(\mathrm{kg} / \mathrm{d})$. Nitrogen efficiency was considered as the ratio of milk $\mathrm{N}$ to $\mathrm{N}$ intake $(\mathrm{g} / \mathrm{g})$. Daily urine volume was estimated based on creatinine concentration $(\mathrm{mg} / \mathrm{L})$ in urine samples collected between d 17 and 19 of each experimental period. Urinary creatinine concentrations were analyzed using commercial kits (kinetic creatinine: catalog no. K-067, Bioclin) in a semi-automatic spectrophotometer (SBA 200, CELM). The ratio of daily creatinine excretion was assumed as $24.05 \mathrm{mg} / \mathrm{kg}$ of BW (Chizzotti et al., 2008).

Microbial protein synthesis was calculated based on the excretion of purine derivatives in urine (uric acid and allantoin) and milk (allantoin), as described by Chen and Gomes (1992). The ratio of purine N to microbial $\mathrm{N}$ was considered to be 0.116 , and the intestinal digestibility of microbial purines was set at 0.83 (Chen and Gomes, 1992). The urinary recovery of absorbed purines and the endogenous contribution of purines were considered to be 0.70 and $0.512 \mathrm{mmol} /$ $\mathrm{kg}$ of $\mathrm{BW}^{0.75}$, respectively (González-Ronquillo et al., 2003). Uric acid concentration in urine was determined using a commercial kit (uric acid stable liquid: catalog no. K-052; Bioclin) and absorbance measured in a spectrophotometer (SBA 200, CELM). Urinary and milk allantoin concentrations were determined according to Fujihara et al. (1987).

Blood samples were collected from all cows by puncture of coccygeal vein on $\mathrm{d} 16,4 \mathrm{~h}$ after the morning feeding. Blood samples were collected in vacutainer tubes for serum and centrifuged $(2,000 \times g$ for $15 \mathrm{~min}$ at $25^{\circ} \mathrm{C}$ ) after clotting. The analyses were performed using colorimetric kits (glucose: catalog no. K-082; urea: catalog no. K-056; Bioclin) and absorbance measured in a spectrophotometer (SBA 200, CELM).

\section{Calculations and Statistical Analysis}

The nutrient intake (NI, $\mathrm{kg} / \mathrm{d}$ ) was calculated accounting for DM offered (OF, $\mathrm{kg} / \mathrm{d}$ ) and the concentration of the nutrient in $\mathrm{OF}(\mathrm{OFc}, \% \mathrm{DM})$, and $\mathrm{DM}$ refused $(\mathrm{RF}, \mathrm{kg} / \mathrm{d})$ and concentration of the nutrient in $\mathrm{DM}$ refused feed $(\mathrm{RFc}, \% \mathrm{DM})$ :

$$
\mathrm{NI}(\mathrm{kg} / \mathrm{d})=\left(\mathrm{OF} \times \frac{\mathrm{OFc}}{100}\right)-\left(\mathrm{RF} \times \frac{\mathrm{RFc}}{100}\right) .
$$

The sorting index (Silveira et al., 2007) was estimated as the intake corresponding to each sieve $\left(\mathrm{P}_{\mathrm{x}} ; \mathrm{x}=1\right.$ to 4) expressed as the percentage of the total predicted intake of animals, in which the predicted intake of $\mathrm{P}_{\mathrm{x}}$ fraction is equal to the ratio between the ingested material (as-fed basis) and the $\mathrm{P}_{\mathrm{x}}$ fraction of the TMR (as-fed basis) according to Equations [1], [2], and [3]:

Predicted intake $(\mathrm{kg} / \mathrm{d})=\mathrm{P}_{\mathrm{xTMR}}(\mathrm{kg} / \mathrm{kg}) \times$ consumed $(\mathrm{kg} / \mathrm{d})$, 
Observed intake $(\mathrm{kg} / \mathrm{d})=$

[amount of feed offered $\left.(\mathrm{kg} / \mathrm{d}) \times \mathrm{P}_{\text {xTMR }}(\mathrm{kg} / \mathrm{kg})\right]$

$-\left[\right.$ amount of feed refused $\left.(\mathrm{kg} / \mathrm{d}) \times \mathrm{P}_{\text {xrefused }}(\mathrm{kg} / \mathrm{kg})\right]$,

$$
\text { Sorting index }=\left(\frac{\text { observed intake }(\mathrm{kg} / \mathrm{d})}{\text { predicted intake }(\mathrm{kg} / \mathrm{d})}\right)
$$

The fecal excretion (FE, $\mathrm{kg} / \mathrm{d}$ ) was calculated dividing iNDF intake (iNDFi, $\mathrm{kg} / \mathrm{d}$ ) by the fecal excretion of iNDF (iNDFf, $\mathrm{kg} / \mathrm{kg}$ ), as follows:

$$
\mathrm{FE}(\mathrm{kg} / \mathrm{d})=\frac{\mathrm{iNDFi}(\mathrm{kg} / \mathrm{d})}{\operatorname{iNDFf}(\mathrm{kg} / \mathrm{kg})}
$$

Apparent total-tract digestibility (ATD, g/ kg) of DM, OM, CP, EE, NDF, and starch were calculated based on fecal excretion ( $\mathrm{FE}, \mathrm{kg} / \mathrm{d})$, nutrient concentration in feces $(\mathrm{NCF}, \mathrm{g} / \mathrm{kg}$ ), and the corresponding nutrient intake (NI, $\mathrm{kg} / \mathrm{d})$ :

$$
\operatorname{ATD}(\mathrm{g} / \mathrm{kg})=\left(\frac{\mathrm{NI}-(\mathrm{FE} \times \mathrm{NCF})}{\mathrm{NI}}\right) \times 100 .
$$

The 3.5\% FCM was calculated according Sklan et al. (1992):

$$
\begin{aligned}
& 3.5 \% \mathrm{FCM}= \\
& {[0.432+0.163 \times \text { fat in milk }(\%)] \times \text { milk yield }(\mathrm{kg} / \mathrm{d})}
\end{aligned}
$$

Feed efficiency was expressed as milk yield $(\mathrm{kg} / \mathrm{d})$ to DMI $(\mathrm{kg} / \mathrm{d})$ ratio. Retained N was calculated subtracting $\mathrm{N}$ intake by $\mathrm{N}$ excretion (fecal, urinary, and milk N).

Data were analyzed using the MIXED procedure of SAS (version 9.3, SAS Institute Inc., Cary, NC) according to the following model:

$$
Y_{i j k l m}=\mu+L_{i}+c_{j: i}+P_{k}+F_{l}+A_{m}+F \times A_{l m}+e_{i j k l m}
$$

with $c_{j: i} \approx N\left(\mathbf{0} ; \sigma_{c}^{2}\right)$ and $e_{i j k l m} \approx N\left(\mathbf{0} ; \sigma_{e}^{2}\right)$, where $Y_{i j k l m}=$ dependent variable of interest; $\mu=$ overall mean; $L_{i}=$ fixed effect of Latin square $(i=1$ to 8$) ; c_{j: i}=$ random effect of cow nested in Latin square $(j=1$ to 32$) ; P_{k}=$ fixed effect of period ( $k=1$ to 4$) ; F_{l}=$ fixed effect of fibrolytic enzyme $(l=1$ to 2$) ; A_{m}=$ fixed effect of amylolytic enzyme $(m=1$ to 2$) ; F \times A_{l m}=$ fixed interaction effect between fibrolytic and amylolytic enzymes; $e_{i j k l m}=$ random error; $N=$ normal distribution; $\sigma_{c}^{2}$ and $\sigma_{e}^{2}$ are variances associated with cow and residual effect, respectively.

Ruminal fermentation variables were analyzed by repeated-measures analysis using the MIXED procedure of SAS (version 9.3) according to the following model:

$$
\begin{aligned}
& Y_{i j k l m n}=\mu+L_{i}+c_{j: i}+P_{k}+F_{l}+A_{m}+F \times A_{l m}+\omega_{i j k l m} \\
& +T_{n}+T \times F_{n l}+T \times A_{n m}+T \times F \times A_{n l m}+e_{i j k l m n},
\end{aligned}
$$

with $\quad c_{j: i} \approx N\left(\mathbf{0} ; \sigma_{c}^{2}\right), \quad \omega_{i j k l m} \approx N\left(\mathbf{0} ; \sigma_{\omega}^{2}\right), \quad$ and $e_{i j k l m n} \approx \operatorname{MVN}(\mathbf{0} ; \mathbf{R})$, where $Y_{i j k l m}=$ dependent variable of interest; $\mu=$ overall mean; $L_{i}=$ fixed effect of Latin square $(i=1$ to 2$) ; c_{j: i}=$ random effect of cow nested in Latin square $(j=1$ to 32$) ; P_{k}=$ fixed effect of period $(k=1$ to 4$) ; F_{l}=$ fixed effect of fibrolytic enzyme $(l=$ 1 to 2$) ; A_{m}=$ fixed effect of amylolytic enzyme $(m=1$ to 2$) ; F \times A_{l m}=$ fixed interaction effect between fibrolytic and amylolytic enzymes; $\omega_{i j k l m}=$ is the random error associated with experimental units; $T_{n}=$ fixed effect of time $(\mathrm{n}=1$ to 9$) ; T \times F_{n l} ; T \times A_{n m}$ and $T \times$ $F \times A_{n l m}$ are interaction terms; $e_{i j k l m n}=$ residual error; $N$ indicates Gaussian distribution; $\sigma_{c}^{2}=$ variance associated with animal; $\sigma_{\omega}^{2}=$ variance associated with random effect of animal; $M V N=$ indicates multivariate normal, and $\mathbf{R}$ is the variance-covariance matrix of residuals due to the repeated measurements. The following variance-covariance matrices were tested: compound symmetry (CS), heterogeneous CS, autoregressive (1), heterogeneous autoregressive (1), Toeplitz (TOEP), heterogeneous TOEP, unstructured, factor analytic (1), and ante-dependence (1). The matrix was selected using the corrected Akaike's information criterion (AICC) method. Means were adjusted by the LSMEANS procedure and interaction effect $F_{l} \times A_{m}$ was decomposed using Fisher's protected least significant difference means test. Statistical differences were declared at $P \leq$ 0.05 and trends toward significance were considered when $0.05<P \leq 0.10$.

\section{RESULTS}

Treatments had no effect $(P \geq 0.111)$ on $\mathrm{DM}$ and nutrient intake. However, an interaction effect $(P=$ 0.024 ) was observed between fibrolytic and amylolytic enzymes for sorting index of feed particles with size between 8 and $19 \mathrm{~mm}$ (Table 2). Amylolytic enzyme addition increased $(P \leq 0.05)$ sorting index of feed particles from 8 to $19 \mathrm{~mm}$ of size, only for cows that did not receive FIB. Furthermore, a main effect was observed for AMY to decrease $(P=0.031)$ preference for feed particles with size higher than $19 \mathrm{~mm}$. Enzyme 
Table 2. Effects of fibrolytic and amylolytic enzymes on nutrient intake, sorting index, and apparent total-tract digestibility of lactating cows

\begin{tabular}{|c|c|c|c|c|c|c|c|c|}
\hline Item & \multicolumn{4}{|c|}{ Treatment $^{1}$} & SEM & \multicolumn{3}{|c|}{$P$-value ${ }^{2}$} \\
\hline \multicolumn{9}{|l|}{ Intake $(\mathrm{kg} / \mathrm{d})$} \\
\hline $\mathrm{OM}$ & 22.5 & 22.2 & 22.4 & 22.4 & 0.23 & 0.356 & 0.754 & 0.398 \\
\hline $\mathrm{NFC}$ & 10.5 & 10.3 & 10.4 & 10.4 & 0.11 & 0.515 & 0.997 & 0.111 \\
\hline NDF & 7.39 & 7.31 & 7.41 & 7.31 & 0.078 & 0.143 & 0.849 & 0.852 \\
\hline \multicolumn{9}{|l|}{ Sorting index } \\
\hline$>19 \mathrm{~mm}$ & 0.834 & 0.867 & 0.825 & 0.819 & 0.0095 & 0.276 & 0.031 & 0.137 \\
\hline $19-8 \mathrm{~mm}$ & $0.983^{\mathrm{b}}$ & $0.986^{\mathrm{ab}}$ & $0.990^{\mathrm{a}}$ & $0.983^{\mathrm{b}}$ & 0.0012 & 0.284 & 0.367 & 0.024 \\
\hline $8-4 \mathrm{~mm}$ & 1.01 & 1.01 & 1.02 & 1.01 & 0.001 & 0.504 & 0.154 & 0.287 \\
\hline$<4 \mathrm{~mm}$ & 1.04 & 1.04 & 1.04 & 1.05 & 0.001 & 0.164 & 0.557 & 0.404 \\
\hline \multicolumn{9}{|c|}{ Apparent total-tract digestibility $(\mathrm{g} / \mathrm{kg}$ ) } \\
\hline Starch & 930 & 938 & 931 & 931 & 1.6 & 0.273 & 0.380 & 0.186 \\
\hline
\end{tabular}

${ }^{\mathrm{a}, \mathrm{b}}$ Fisher means test (LSD) at 0.05 of probability.

${ }^{1}$ Control (CON), no exogenous enzyme supplementation; fibrolytic enzyme (FIB), Fibrozyme (Alltech Inc., Nicholasville, KY) provided at 12 $\mathrm{g} / \mathrm{d}(1 \mathrm{~g} / \mathrm{kg}$ of concentrate on an as-fed basis); amylolytic enzyme (AMY), Amaize (Alltech Inc.) provided at $8 \mathrm{~g} / \mathrm{d}(0.66 \mathrm{~g} / \mathrm{kg}$ of concentrate on an as-fed basis); and FIB + AMY (1 g of Fibrozyme and $0.66 \mathrm{~g}$ of Amaize per $\mathrm{kg}$ of concentrate on an as-fed basis).

${ }^{2}$ Probabilities for fibrolytic enzyme effect (FIB), amylolytic enzyme effect (AMY), and interaction effect of fibrolytic and amylolytic enzymes $(\mathrm{FIB} \times \mathrm{AMY})$.

addition showed no effect $(P \geq 0.186)$ on DM, OM, NDF, CP, EE, and starch digestibility.

Enzymes had no effect $(P \geq 0.112)$ on ruminal $\mathrm{pH}$ and ruminal concentrations of $\mathrm{NH}_{3}-\mathrm{N}$, acetate, propionate, branched-chain fatty acids, and VFA (Table 3). An interaction effect $(P=0.043)$ was observed between FIB and AMY for ruminal butyric acid concentration.
The addition of AMY increased $(P \leq 0.05)$ ruminal butyrate concentration only in cows not treated with FIB. However, FIB had no effect $(P>0.05)$ on butyric acid concentration in the rumen of animals fed diets either with or without AMY.

Fibrolytic and amylolytic enzymes had no effect $(P$ $\geq 0.372$ ) on yields of milk, FCM, and milk fat (Table

Table 3. Effects of fibrolytic and amylolytic enzymes on ruminal fermentation of lactating cows

\begin{tabular}{|c|c|c|c|c|c|c|c|c|}
\hline \multirow[b]{2}{*}{ Item } & \multicolumn{4}{|c|}{ Treatment $^{1}$} & \multirow[b]{2}{*}{ SEM } & \multicolumn{3}{|c|}{$P$-value ${ }^{2}$} \\
\hline & $\mathrm{CON}$ & FIB & AMY & $\mathrm{FIB}+\mathrm{AMY}$ & & FIB & AMY & $\mathrm{FIB} \times \mathrm{AMY}$ \\
\hline $\mathrm{pH}$ & 6.06 & 6.07 & 6.06 & 6.02 & 0.033 & 0.589 & 0.488 & 0.536 \\
\hline $\mathrm{NH}_{3}-\mathrm{N}(\mathrm{mg} / \mathrm{dL})$ & 18.7 & 19.7 & 19.1 & 20.4 & 0.45 & 0.112 & 0.439 & 0.827 \\
\hline Acetate $(\mathrm{mmol} / 100 \mathrm{mmol})$ & 54.3 & 53.8 & 54.5 & 54.3 & 0.29 & 0.409 & 0.369 & 0.865 \\
\hline Propionate (mmol/100 mmol) & 23.5 & 23.8 & 22.7 & 23.7 & 0.31 & 0.260 & 0.437 & 0.589 \\
\hline Butyrate $(\mathrm{mmol} / 100 \mathrm{mmol})$ & $16.4^{\mathrm{b}}$ & $16.9^{\mathrm{ab}}$ & $17.6^{\mathrm{a}}$ & $16.9^{\mathrm{ab}}$ & 0.26 & 0.846 & 0.094 & 0.043 \\
\hline Total $\mathrm{BCFA}^{3}(\mathrm{mmol} / 100 \mathrm{mmol})$ & 5.27 & 5.1 & 5.21 & 5.16 & 0.049 & 0.990 & 0.295 & 0.584 \\
\hline Total VFA $(\mathrm{m} M)$ & 94.7 & 94.9 & 94.8 & 94.9 & 0.05 & 0.946 & 0.278 & 0.744 \\
\hline Acetate:propionate & 2.28 & 2.44 & 2.29 & 2.56 & 0.035 & 0.404 & 0.155 & 0.332 \\
\hline Acetate $(\mathrm{m} M)$ & 51.5 & 51.7 & 51.1 & 51.5 & 0.26 & 0.314 & 0.330 & 0.751 \\
\hline Propionate $(\mathrm{m} M)$ & 22.3 & 21.5 & 22.6 & 22.5 & 0.30 & 0.268 & 0.476 & 0.605 \\
\hline Butyrate $(\mathrm{m} M)$ & $15.5^{\mathrm{b}}$ & $16.1^{\mathrm{ab}}$ & $16.7^{\mathrm{a}}$ & $16.0^{\mathrm{ab}}$ & 0.24 & 0.842 & 0.077 & 0.038 \\
\hline
\end{tabular}

$\overline{a, b}$ Means within a row with different superscripts differ.

${ }^{1}$ Control (CON), no exogenous enzyme supplementation; fibrolytic enzyme (FIB), Fibrozyme (Alltech Inc., Nicholasville, KY) provided at 12 $\mathrm{g} / \mathrm{d}(1 \mathrm{~g} / \mathrm{kg}$ of concentrate on an as-fed basis); amylolytic enzyme (AMY), Amaize (Alltech Inc.) provided at $8 \mathrm{~g} / \mathrm{d}(0.66 \mathrm{~g} / \mathrm{kg}$ of concentrate on an as-fed basis); and FIB + AMY (1 g of Fibrozyme and $0.66 \mathrm{~g}$ of Amaize per $\mathrm{kg}$ of concentrate on an as-fed basis).

${ }^{2}$ Probabilities for fibrolytic enzyme effect (FIB), amylolytic enzyme effect (AMY), and interaction effect of fibroytic and amylolytic enzymes $(\mathrm{FIB} \times \mathrm{AMY})$.

${ }^{3}$ Branched-chain fatty acids (BCFA). 
Table 4. Effects of fibrolytic and amylolytic enzymes on performance of lactating cows

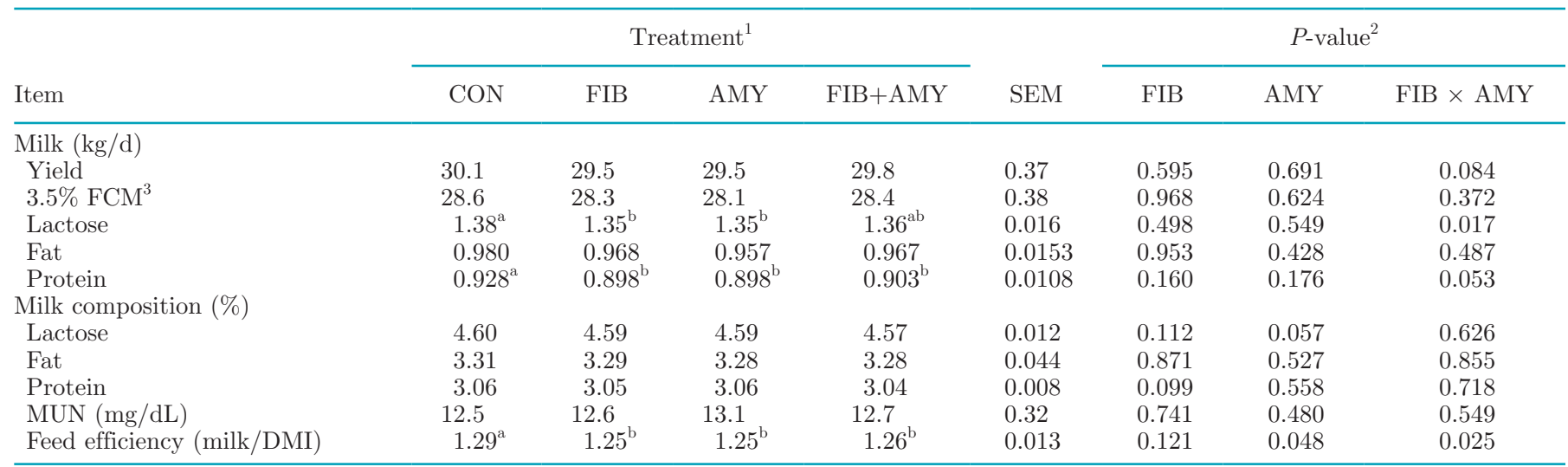

${ }^{\mathrm{a}, \mathrm{b}}$ Means within a row with different superscripts differ.

${ }^{1}$ Control (CON), no exogenous enzyme supplementation; fibrolytic enzyme (FIB), Fibrozyme (Alltech Inc., Nicholasville, KY) provided at 12 $\mathrm{g} / \mathrm{d}(1 \mathrm{~g} / \mathrm{kg}$ of concentrate on an as-fed basis); amylolytic enzyme (AMY), Amaize (Alltech Inc.) provided at $8 \mathrm{~g} / \mathrm{d}$ (0.66 g/kg of concentrate on an as-fed basis); and FIB + AMY ( $1 \mathrm{~g}$ of Fibrozyme and $0.66 \mathrm{~g}$ of Amaize per $\mathrm{kg}$ of concentrate on an as-fed basis).

${ }^{2}$ Probabilities for fibrolytic enzyme effect (FIB), amylolytic enzyme effect (AMY), and interaction effect of fibrolytic and amylolytic enzymes $(\mathrm{FIB} \times \mathrm{AMY})$.

${ }^{3}$ Calculated according to Sklan et al. (1992).

4). However, FIB tended to decrease $(P=0.099)$ milk protein concentration, regardless of AMY. In addition, an interaction effect $(P \leq 0.053)$ was observed between FIB and AMY for lactose and protein production, and feed efficiency. The FIB decreased $(P \leq 0.05)$ protein production and feed efficiency only in animals that did not receive AMY. Furthermore, AMY decreased $(P=$ $0.044)$ urinary $\mathrm{N}$ excretion of cows, without affecting $(P \geq 0.194) \mathrm{N}$ balance (Table 5). Enzymes showed no effect $(P \geq 0.112)$ on $\mathrm{N}$ intake and fecal excretion, microbial protein synthesis, serum glucose, and urea concentration. A tendency $(P=0.094)$ was observed for the interaction effect between fibrolytic and amylo- lytic enzymes on milk $\mathrm{N}$ secretion and $\mathrm{N}$ intake ratio. Fibrolytic enzyme decreased $(P \leq 0.05)$ milk N secretion only in animals not treated with AMY.

\section{DISCUSSION}

Refuting our initial hypothesis, this study showed no effects of enzyme supplements on DMI, ruminal fermentation, and lactation performance. Previous studies of our research group demonstrated that different doses of both amylolytic and fibrolytic enzyme products had no effect on milk production and composition of midlactation cows (Silva et al., 2016; Takiya et al., 2017).

Table 5. Effects of fibrolytic and amylolytic enzymes on nitrogen utilization, microbial protein synthesis, blood metabolites, and BW of lactating cows

\begin{tabular}{|c|c|c|c|c|c|c|c|c|}
\hline \multirow[b]{2}{*}{ Item } & \multicolumn{4}{|c|}{ Treatment $^{1}$} & \multirow[b]{2}{*}{ SEM } & \multicolumn{3}{|c|}{$P$-value ${ }^{2}$} \\
\hline & $\mathrm{CON}$ & FIB & AMY & $\mathrm{FIB}+\mathrm{AMY}$ & & FIB & AMY & $\mathrm{FIB} \times \mathrm{AMY}$ \\
\hline Fecal N (g/g N intake) & 0.369 & 0.373 & 0.374 & 0.361 & 0.0046 & 0.584 & 0.662 & 0.279 \\
\hline Urinary N (g/g N intake) & 0.228 & 0.212 & 0.203 & 0.200 & 0.0045 & 0.322 & 0.044 & 0.431 \\
\hline Milk N (g/g N intake) & $0.221^{\mathrm{a}}$ & $0.213^{\mathrm{b}}$ & $0.214^{\mathrm{b}}$ & $0.214^{\mathrm{b}}$ & 0.0020 & 0.046 & 0.157 & 0.094 \\
\hline $\mathrm{N}$ balance (g/g N intake) & 0.192 & 0.201 & 0.210 & 0.218 & 0.0064 & 0.513 & 0.194 & 0.957 \\
\hline Blood urea $(\mathrm{mg} / \mathrm{dL})$ & 37.3 & 36.2 & 36.4 & 36.5 & 0.81 & 0.476 & 0.633 & 0.440 \\
\hline $\mathrm{BW}(\mathrm{kg})$ & 582 & 580 & 580 & 579 & 5.7 & 0.171 & 0.377 & 0.974 \\
\hline BW change $(\mathrm{kg} / \mathrm{d})$ & 0.334 & 0.517 & 0.320 & 0.331 & 0.0592 & 0.397 & 0.382 & 0.454 \\
\hline
\end{tabular}

${ }^{1}$ Control (CON), no exogenous enzyme supplementation; fibrolytic enzyme (FIB), Fibrozyme (Alltech Inc., Nicholasville, KY) provided at 12 $\mathrm{g} / \mathrm{d}(1 \mathrm{~g} / \mathrm{kg}$ of concentrate on an as-fed basis); amylolytic enzyme (AMY), Amaize (Alltech Inc.) provided at $8 \mathrm{~g} / \mathrm{d}$ (0.66 g/kg of concentrate on an as-fed basis); and FIB + AMY ( $1 \mathrm{~g}$ of Fibrozyme and $0.66 \mathrm{~g}$ of Amaize per $\mathrm{kg}$ of concentrate on an as-fed basis).

${ }^{2}$ Probabilities for fibrolytic enzyme effect (FIB), amylolytic enzyme effect (AMY), and interaction effect of fibrolytic and amylolytic enzymes $($ FIB $\times$ AMY $)$. 
No differences in DMI of cows fed exogenous enzymes have been reported in a meta-analysis evaluating fibrolytic enzymes (Arriola et al., 2017) and in studies using amylase (Tricarico et al., 2005; Vargas-Rodriguez et al., 2014; Takiya et al., 2017). The single study that evaluated the combination of fibrolytic and amylolytic enzymes (Hristov et al., 2008) also did not report effects of enzymes on DMI and ruminal fermentation of dairy cows.

Although Yang et al. (2000) observed no effect of fibrolytic enzyme on nutrient intake, the enzyme increased the DM, OM, and CP digestibility in lactating cows. Beauchemin et al. (2003) found an increase in DMI of dairy cattle fed a fibrolytic enzyme, which was attributed to improved ruminal particulate passage rate and fiber digestion. Furthermore, increased DM and NDF digestibility without affecting DMI when providing fibrolytic enzyme products to ruminants have been reported in the literature (Beauchemin et al., 1995; Rode et al., 1999). The increase in nutrient digestibility is related to the mode of action of the enzyme; when applied before feeding, the enzyme alters the structure of the feed, making it more susceptible to degradation (Dean et al., 2013). In addition, the synergism between endogenous and exogenous enzymes increases overall ruminal enzymatic activity and hydrolysis (Morgavi et al., 2000), improving the diet digestibility. However, none of these effects were observed in the present study. The response to enzyme supplementation would likely be greater when cows experience a limited DMI; for example, during the transition period or when cows are fed diets with low energy density (Gencoglu et al., 2010). In situations that DMI is not limited, enzymes are expected to increase the rate of degradation but not the extension, resulting in no improvements of animal performance. However, the magnitude of enzyme effects on ruminal degradation was possibly lower than expected in the present study. In addition, we could speculate that increased NFC hydrolysis could reduce microbial adhesion (Miron et al., 2001), thus having a negative effect on ruminal degradation instead.

Agreeing with the current study, amylolytic enzymes have not affected DMI, DM digestibility, and milk production (Ferraretto et al., 2011; Nozière et al., 2014). Chen et al. (1995) did not observe effects on DMI and starch digestibility but reported an increase in $\mathrm{CP}$ digestibility when feeding $\alpha$-amylase to dairy cows. Similarly, Gencoglu et al. (2010) found an increase in $\mathrm{DM}, \mathrm{CP}$, and NDF digestibility when cows were fed a low starch diet supplemented with exogenous amylase. The increase in DM, OM, CP, and NDF digestibility reported by Chen et al. (1995) and Gencoglu et al. (2010) can be supported by the findings of Tricarico et al. (2008). Diet supplementation with $\alpha$-amylase increased the production of maltodextrins, a substrate for a variety of ruminal bacteria, including amylolytic and nonamylolytic bacteria (Tricarico et al., 2008), ultimately increasing the overall nutrient digestibility. As suggested by Takiya et al. (2017), the lack of $\alpha$-amylase effect on starch total-tract digestibility could be associated with increased postruminal compensatory starch digestion, in response to increased ruminal degradation; lack of enzyme effect on ruminal starch degradation; or starch fermentation in another digestive compartment.

According to Leonardi and Armentano (2003), dairy cows avoid larger particles and prefer smaller particles when fed TMR. Positive effects of fibrolytic (Rode et a., 1999) and amylolytic (Gencoglu et al., 2010; Weiss et al., 2011) enzymes on NDF digestibility could be associated with animal preference for larger feed particles that contain higher NDF content. However, in the present study, AMY decreased the intake of larger feed particles $(>19 \mathrm{~mm})$, and increased intake of feed particles between 8 and $19 \mathrm{~mm}$, without major effects either on starch and NDF digestibility or total feed intake. A relatively low intake of physically effective fiber by animals can be associated with the lack of enzyme effects on nutrient digestibility and decreased feed efficiency. Preference for feed particles with higher energy is expected when fiber requirement (longer particles) is achieved (Miller-Cushon and DeVries, 2017). DeVries et al. (2008) observed that lactating cows select few longer feed particles and prefer intermediate-size feed particles in diets with $>60 \%$ of forage, and the opposite happens in diets with less than $50 \%$ of forage. According to Keunen et al. (2002), dairy cows would increase their dietary preference for a feed with longer particle size when they present low ruminal $\mathrm{pH}$. Although positive effect was observed on intermediate particle intake and butyrate ruminal concentration, AMY showed no effect on ruminal $\mathrm{pH}$ in the present study.

Results of the current study agree with the small effects of enzyme effects on ruminal fermentation reported in the literature (Bowman et al., 2002; Tricarico et al., 2005; Silva et al., 2016; Takiya et al., 2017). Bowman et al. (2002) found an increase in ruminal propionate concentration and a decrease in acetate to propionate ratio with fibrolytic enzyme dietary supplementation. In contrast with the current study, these authors observed improvements in NDF digestibility and milk production, which might have occurred because of the increased ruminal enzyme activity and greater availability of fermentable soluble carbohydrates. Tricarico et al. (2005) suggested that the increased milk production in cows receiving $\alpha$-amylase was apparently mediated by changes in molar proportions of ruminal VFA without affecting ruminal starch digestibility. These authors reported changes in microbial popula- 
tions and increased ruminal butyrate concentration in cows supplied $\alpha$-amylase (Aspergillus oryzae extract) cows. The increase in ruminal butyrate concentration in cows fed amylolytic enzyme, as described by Tricarico et al. (2008), did not reflect in changes of ruminal propionate concentration or milk yield. The increased ruminal butyrate concentration that occurred in the present study could be associated with the growth of nonamylolytic bacteria. Bacteria such as Butyrivibrio fibrisolvens D1, Selenomonas ruminantium GA192, and Megasphaera elsdenii T81 grow faster in cultures with starch and addition of amylase (Tricarico et al., 2008). Furthermore, these bacteria degrade fiber (Butyrivibrio fibrisolvens D1) and present high proteolytic activity (Megasphaera elsdenii T81), whereas the main product of their fermentation is butyrate. Tricarico et al. (2008) suggested that the mode of action of $\alpha$-amylase involves the production of oligosaccharides from amylose and amylopectin. These oligosaccharides can be used by amylolytic and nonamylolytic bacteria in cross-feeding mechanisms that modify the products of fermentation in the rumen. However, as observed in this study, Hristov et al. (2008) found no effect on the ruminal $\mathrm{pH}$ VFA profile in lactating cows fed both xylanase and $\alpha$-amylase.

In the present study, amylolytic enzymes decreased urinary $\mathrm{N}$ excretion. However, other authors reported no effect of amylolytic enzymes on $\mathrm{N}$ excretion (Nozière et al., 2014; Takiya et al., 2017). Additionally, fibrolytic enzymes decreased milk $\mathrm{N}$ secretion in accordance with the trend for lower milk protein concentration. Silva et al. (2016) reported a linear reduction in milk $\mathrm{N}$ secretion with increasing doses of fibrolytic enzyme. As previously discussed, the lower intake of physically effective NDF and increased activity of microorganisms with high proteolytic activity could be related to the decreased $\mathrm{N}$ utilization efficiency of AMY-treated animals. In this study, fibrolytic enzyme had no effect on urinary $\mathrm{N}$ excretion or milk urea concentration of dairy cows. Tricarico et al. (2005) and Takiya et al. (2017) showed no differences in blood urea and glucose concentration when supplementing diets for lactating cows with amylolytic enzymes. The results from the current study are similar to those reported by Peters et al. (2015) and Silva et al. (2016), which also found no effects of fibrolytic enzymes on serum glucose and urea concentrations.

The current study showed no improvements in milk yield and composition of cows fed enzymes. Indeed, regardless of the microbial origin (bacterial or fungal), enzyme products have not altered milk yield and composition of mid-lactating cows, neither fibrolytic (Dean et al., 2013; Peters et al., 2015; Silva et al., 2016) nor amylolytic enzymes (Ferraretto et al., 2011; Vargas-
Rodriguez et al., 2014; Takiya et al., 2017). Recently, Arriola et al. (2017) performed a meta-analysis of 15 studies that evaluated effects of supplementing fibrolytic enzymes on performance of dairy cows and they reported a numerically but not significantly increase in milk production response relative to several enzyme preparations. However, according to Beauchemin and Holtshausen (2010) the stage of lactation and energy status appear to be critical in terms of positive response to enzyme additives.

Several factors may influence animal response to enzyme supplementation, such as the product preparation, dose, enzymatic activity (Arriola et al., 2017), supply method (Kung et al., 2002), diet fraction which enzyme is added (concentrate, TMR, or silage; Bowman et al., 2002), stability of the enzymes in the rumen (McAllister et al., 2001), mechanism of action (Beauchemin and Holtshausen, 2010), and basal diet composition (Gandra et al., 2017; Tirado-González et al., 2018). It is still a challenge for ruminant nutritionists to recommend enzyme supplements because results invariably have small magnitude and are inconsistent in the literature. In addition, the most positive effects of enzyme supplements have been reported in specific conditions such as diets with low starch content, and forage sources with low degradability. This study showed no evidence that the combination of amylolytic and fibrolytic enzymes can improve the performance of mid-lactation cows.

\section{ACKNOWLEDGMENTS}

The authors thank Alltech Inc. (Nicholasville, KY) for providing funding and assistance to carry out this work. Authors appreciate São Paulo Research Foundation (FAPESP, São Paulo, Brazil) for the fellowship provided to E. M. C. Zilio (grant \#2016/15711-8).

\section{REFERENCES}

Andreazzi, A. S. R., M. N. Pereira, R. B. Reis, A. N. Pereira, N. N. Morais Junior, A. S. Acedo, R. G. Hermes, and C. S. Cortinhas. 2018. Effect of exogenous amylase on lactation performance of dairy cows fed a high-starch diet. J. Dairy Sci. 101:7199-7207. https://doi.org/10.3168/jds.2017-14331.

AOAC International. 2000. Official Methods of Analysis. 17th ed. AOAC Int., Arlington, VA.

Arriola, K. G., A. S. Oliveira, X. Z. Ma, I. J. Lean, M. C. Giurcanu, and A. T. Adesogan. 2017. A meta-analysis on the effect of dietary application of exogenous fibrolytic enzymes on the performance of dairy cows. J. Dairy Sci. 100:4513-4527. https://doi.org/10.3168/ jds.2016-12103.

Beauchemin, K. A., D. Colombatto, D. P. Morgavi, and W. Z. Yang. 2003. Use of exogenous fibrolytic enzymes to improve feed utilization by ruminants. J. Anim. Sci. 81:37-47.

Beauchemin, K. A., and L. Holtshausen. 2010. Developments in enzyme usage in ruminants. Pages 206-230 in Enzymes in Farm Animal Nutrition. 2nd ed. CAB Int., Wallingford, UK.

Beauchemin, K. A., and L. M. Rode. 1996. Use of feed enzymes in ruminant nutrition. Pages 103-130 in Animal Science Research and 
Development-Meeting Future Challenges. L. M. Rode, ed. Minister of Supply and Services Canada, Ottawa, ON, Canada.

Beauchemin, K. A., L. M. Rode, and V. J. Sewalt. 1995. Fibrolytic enzymes increase fiber digestibility and growth rate of steers fed dry forages. Can. J. Anim. Sci. 75:641-644. https://doi.org/10.4141/ cjas95-096.

Bowman, G. R., K. A. Beauchemin, and J. A. Shelford. 2002. The proportion of the diet to which fibrolytic enzymes are added affects nutrient digestion by lactating dairy cows. J. Dairy Sci. 85:34203429. https://doi.org/10.3168/jds.S0022-0302(02)74430-5.

Broderick, G. A., and M. K. Clayton. 1997. A statistical evaluation of animal and nutritional factors influencing concentrations of milk urea nitrogen. J. Dairy Sci. 80:2964-2971. https://doi.org/10 .3168/jds.S0022-0302(97)76262-3.

Broderick, G. A., and J. H. Kang-Meznarich. 1980. Automated simultaneous determination of ammonia and total amino-acids in ruminal fluid and in vitro media. J. Dairy Sci. 63:64-75. https:// doi.org/10.3168/jds.S0022-0302(80)82888-8.

Burroughs, W., W. Woods, S. A. Ewing, J. Greig, and B. Theurer. 1960. Enzyme additions to fattening cattle rations. J. Anim. Sci. 19:458-464. https://doi.org/10.2527/jas1960.192458x.

Casali, A. O., E. Detmann, S. C. Valadares Filho, J. C. Pereira, L. T. Henriques, S. G. Freitas, and M. F. Paulino. 2008. Influence of incubation time and particles size on indigestible compounds contents in cattle feeds and feces obtained by in situ procedures. Braz. J. Anim. Sci. 37:335-342. https://doi.org/10.1590/S1516 $-35982008000200021$.

Chen, K. H., J. T. Huber, J. Simas, C. B. Theurer, P. Yu, S. C. Chan, F. Santos, Z. Wu, and R. S. Swingle. 1995. Effect of enzyme treatment or steam-flaking of sorghum grain on lactation and digestion in dairy cows. J. Dairy Sci. 78:1721-1727. https://doi.org/10 $.3168 /$ jds.S0022-0302(95)76797-2.

Chen, X. B., and M. J. Gomes. 1992. Estimation of microbial protein supply to sheep and cattle based on urinary excretion of purine derivate. Page 21 in Overview of Technical Details. International Feed Research Unit. Rowett Research Institute, Bucksburn, Aberdeen, Scotland.

Chizzotti, M. L., S. C. Valadares Filho, R. F. D. Valadares, F. H. M. Chizzotti, and L. O. Tedeschi. 2008. Determination of creatinine excretion and evaluation of spot urine sampling in Holstein cattle. Livest. Sci. 113:218-225. https://doi.org/10.1016/j.livsci.2007.03 .013 .

Dean, D. B., C. R. Staples, R. C. Littell, S. Kim, and A. T. Adesogan. 2013. Effect of method of adding a fibrolytic enzyme to dairy cow diets on feed intake digestibility, milk production, ruminal fermentation, and blood metabolites. Anim. Nutr. Feed Technol. $13: 337-353$.

DeFrain, J. M., A. R. Hippen, K. F. Kascheur, and J. M. Tricarico. 2005. Effects of dietary $\alpha$-amylase on metabolism and performance of transition dairy cows. J. Dairy Sci. 88:4405-4413. https://doi .org/10.3168/jds.S0022-0302(05)73127-1.

DeVries, T. J., F. Dohme, and K. A. Beauchemin. 2008. Repeated ruminal acidosis challenges in lactating dairy cows at high and low risk for developing acidosis: Feed sorting. J. Dairy Sci. 91:3958 3967. https://doi.org/10.3168/jds.2008-1347.

DiLorenzo, N., D. R. Smith, M. J. Quinn, M. L. May, C. H. Ponce, W. Steinberg, M. A. Engstrom, and M. L. Galyean. 2011. Effects of grain processing and supplementation with exogenous amylase on nutrient digestibility in feedlot diets. Livest. Sci. 137:178-184. https://doi.org/10.1016/j.livsci.2010.11.003.

Ferraretto, L. F., R. D. Shaver, M. Espineira, H. Gencoglu, and S. J. Bertic. 2011. Influence of a reduced-starch diet with or without exogenous amylase on lactation performance by dairy cows. J. Dairy Sci. 94:1490-1499. https://doi.org/10.3168/jds.2010-3736.

Ferreira, E. M., M. V. C. Ferraz Júnior, D. M. Polizel, F. S. Urano, I. Susin, R. S. Gentil, M. V. Biehl, J. S. Biava, and A. V. Pires. 2018. Milk yield and composition from ewes fed raw soybeans and their lambs' performance. Anim. Feed Sci. Technol. 238:1-8. https://doi .org/10.1016/j.anifeedsci.2018.01.011.

Food Chemicals Codex. 1996. 4th ed. National Academic Press, Washington, DC.
Fujihara, T., E. R. Orskov, P. J. Reeds, and D. J. Kyle. 1987. The effect of protein infusion on urinary excretion of purine derivates in ruminants nourished by intragastric nutrition. J. Agric. Sci. 109:7-12. https://doi.org/10.1017/S0021859600080916.

Gandra, J. R., G. A. Miranda, R. H. T. B. Goes, C. S. Takiya, T. A. Del Valle, E. R. Oliveira, J. E. Freitas Junior., E. R. S. Gandra, H. M. C. Araki, and A. L. A. V. Santos. 2017. Fibrolytic enzyme supplementation through ruminal bolus on eating behavior, nutrient digestibility and ruminal fermentation in Jersey heifers fed either corn silage- or sugarcane silage-based diets. Anim. Feed Sci. Technol. 231:29-37. https://doi.org/10.1016/j.anifeedsci.2017.06.009.

Gencoglu, H., R. D. Shaver, W. Steinberg, J. Ensink, L. F. Ferraretto, S. J. Bertics, J. C. Lopes, and M. S. Akins. 2010. Effect of feeding a reduced-starch diet with or without amylase addition on lactation performance in dairy cows. J. Dairy Sci. 93:723-732. https:// doi.org/10.3168/jds.2009-2673.

González-Ronquillo, M., J. Balcells, J. A. Guada, and F. Vicente. 2003. Purine derivate excretion in dairy cows: Endogenous excretion and the effect of exogenous nucleic acid supply. J. Dairy Sci. 86:1282-1291. https://doi.org/10.3168/jds.S0022-0302(03)73712 $-6$.

Hall, M. B. 2000. Calculation of non structural carbohydrate content of feeds that contain non-protein nitrogen. Bulletin 339. University of Florida, Gainesville.

Hendrix, D. L. 1993. Rapid extraction and analysis of nonstructural carbohydrates in plant tissues. Crop Sci. 33:1306-1311. https://doi .org/10.2135/cropsci1993.0011183X003300060037x.

Hristov, A. N., C. E. Basel, A. Melgar, A. E. Foley, J. K. Ropp, C. W. Hunt, and J. M. Tricarico. 2008. Effect of exogenous polysaccharide-degrading enzyme preparations on ruminal fermentation and digestibility of nutrients in dairy cows. Anim. Feed Sci. Technol. 145:182-193. https://doi.org/10.1016/j.anifeedsci.2007.05.051.

Huhtanen, P., K. Kaustell, and S. Jaakkola. 1994. The use of internal markers to predict total digestibility and duodenal flow of nutrients in cattle given six different diets. Anim. Feed Sci. Technol. 48:211-227. https://doi.org/10.1016/0377-8401(94)90173-2.

Keunen, J. E., J. C. Plaizier, L. Kyriazakis, T. F. Duffield, T. M. Widowski, M. I. Lindinger, and B. W. McBride. 2002. Effects of a subacute ruminal acidosis model on the diet selection of dairy cows. J. Dairy Sci. 85:3304-3313. https://doi.org/10.3168/jds .S0022-0302(02)74419-6.

Klingerman, C. M., W. Hu, E. E. McDonell, M. C. DerBedrosian, and L. Kung Jr.. 2009. An evaluation of exogenous enzymes with amylolytic activity for dairy cows. J. Dairy Sci. 92:1050-1059. https:/ /doi.org/10.3168/jds.2008-1339.

Kung, L. Jr., M. A. Cohen, L. M. Rode, and R. J. Treacher. 2002. The effect of fibrolytic enzymes sprayed onto forages and fed in a total mixed ration to lactating dairy cows. J. Dairy Sci. 85:2396-2402. https://doi.org/10.3168/jds.S0022-0302(02)74321-X.

Leonardi, C., and L. E. Armentano. 2003. Effect of quantity, quality and length of alfalfa hay on selective consumption by dairy cows. J. Dairy Sci. 86:557-564. https://doi.org/10.3168/jds.S0022 -0302(03)73634-0.

Machado, M. G., E. Detmann, H. C. Mantovani, S. C. Valadares Filho, C. P. B. Bento, M. I. Marcondes, and A. S. Assunção. 2016. Evaluation of the length of adaptation period for changeover and crossover nutritional experiments with cattle fed tropical forage-based diets. Anim. Feed Sci. Technol. 222:132-148. https://doi.org/10 .1016/j.anifeedsci.2016.10.009.

McAllister, T. A., A. N. Hristov, K. A. Beauchemin, L. M. Rode, and K. J. Cheng. 2001. Enzymes in ruminant diets. Pages 273-298 in Enzymes in Farm Animal Nutrition. M. R. Bedford and G. G. Partridge, ed. CABI Publishing, Marlborough, Wiltshire, UK.

McCarthy, M. M., M. A. Engstrom, E. Azem, and T. F. Gressley. 2013. The effect of an exogenous amylase on performance and total-tract digestibility in lactating dairy cows fed a high-byproduct diet. J. Dairy Sci. 96:3075-3084. https://doi.org/10.3168/jds.2012-6045.

Miller-Cushon, E. K., and T. J. DeVries. 2017. Feed sorting in dairy cattle: Causes, consequences, and management. J. Dairy Sci. 100:4172-4183. 
Miron, J., D. Ben-Ghedalla, and M. Morrison. 2001. Invited review: Adhesion mechanisms of rumen cellulolytic bacteria. J. Dairy Sci. 84:1294-1309. https://doi.org/10.3168/jds.S0022 -0302(01)70159-2.

Morgavi, D. P., K. A. Beauchemin, V. L. Nsereko, L. M. Rode, A. D. Iwaasa, W. Z. Yang, T. A. McAllister, and Y. Wang. 2000. Synergy between ruminal fibrolytic enzymes and enzymes from Trichoderma Longibrachiatum. J. Dairy Sci. 83:1310-1321. https:/ /doi.org/10.3168/jds.S0022-0302(00)74997-6.

NRC. 2001. Nutrient Requirements of Dairy Cattle. 7th rev. ed. Natl. Acad. Sci., Washington, DC.

Nozière, P., W. Steinberg, M. Silberberg, and D. P. Morgavi. 2014. Amylase addition increases starch ruminal digestion in first-lactation cows fed high and low starch diets. J. Dairy Sci. 97:2319-2328. https://doi.org/10.3168/jds.2013-7095.

Oba, M., and M. S. Allen. 1999. Evaluation of the importance of the digestibility of neutral detergent fiber from forage: effects on dry matter intake and milk yield of dairy cows. J. Dairy Sci. 82:589 596. https://doi.org/10.3168/jds.S0022-0302(99)75271-9.

Peters, A., M. Ulrich, and S. Danicke. 2015. Effect of exogenous fibrolytic enzymes on performance and blood profile in early and midlactation cows. Anim. Nutr. 1:229-238. https://doi.org/10.1016/j .aninu.2015.09.001.

Rode, L. M., W. Z. Yang, and K. A. Beauchemin. 1999. Fibrolytic enzyme supplements for dairy cows in early lactation. J. Dairy Sci. 82:2121-2126. https://doi.org/10.3168/jds.S0022-0302(99)75455 $-\mathrm{X}$.

Silva, T. H., C. S. Takiya, T. H. A. Vendramini, E. Ferreira de Jesus, F. Zanferari, and F. P. Rennó. 2016. Effects of dietary fibrolytic enzymes on chewing time, ruminal fermentation, and performance of mid-lactating dairy cows. Anim. Feed Sci. Technol. 221:35-43. https://doi.org/10.1016/j.anifeedsci.2016.08.013.

Silveira, C., M. Oba, W. Z. Yang, and K. A. Beauchemin. 2007. Selection of barley grain affects ruminal fermentation, starch digestibility, and productivity of lactating dairy cows. J. Dairy Sci. 90:2860-2869. https://doi.org/10.3168/jds.2006-771.

Sklan, D. R., R. Ashkenazi, A. Braun, A. Devorin, and K. Tabori. 1992. Fatty acids, calcium soaps of fatty acids, and cottonseeds fed to high yielding cows. J. Dairy Sci. 75:2463-2472. https://doi.org/ 10.3168/jds.S0022-0302(92)78008-4.
Sujani, S., and R. T. Seresinhe. 2015. Exogenous enzymes in ruminant nutrition: A review. Asian J. Anim. Sci. 93:85-99. https://doi.org/ 10.3923/ajas.2015.85.99.

Takiya, C. S., G. D. Calomeni, T. H. Silva, T. H. A. Vendramini, G. G. Silva, C. E. C. Consentini, J. C. Bertoni, E. M. C. Zilio, and F. P. Rennó. 2017. Increasing dietary doses of an Aspergillus oryzae extract with alpha-amylase activity on nutrient digestibility and ruminal fermentation of lactating dairy cows. Anim. Feed Sci. Technol. 228:159-167. https://doi.org/10.1016/j.anifeedsci.2017 .04.017.

Tirado-González, D. N., L. A. Miranda-Romero, A. Ruíz-Flores, S. E. Medina-Cuéllar, R. Ramírez-Valverde, and G. Tirado-Estrada. 2018. Meta-analysis: Effects of exogenous fibrolytic enzymes in ruminant diets. J. Appl. Anim. Res. 46:771-783. https://doi.org/ 10.1080/09712119.2017.1399135.

Tricarico, J. M., J. D. Johnston, and K. A. Dawson. 2008. Dietary supplementation of ruminant diets with an Aspergillus oryzae a-amylase. Anim. Feed Sci. Technol. 145:136-150. https://doi.org/ 10.1016/j.anifeedsci.2007.04.017.

Tricarico, J. M., J. D. Johnston, K. A. Dawson, K. C. Hanson, K. R. McLeod, and D. L. Harmon. 2005. The effects of an Aspergillus oryzae extract containing alpha-amylase activity on ruminal fermentation and milk production in lactating Holstein cows. J. Anim. Sci. 81:365-374. https://doi.org/10.1079/ASC50410365.

Undersander, D., D. R. Mertens, and N. Theix. 1992. Forage Analysis. Page 139 in National Forage Testing Association, USA. National Forage Testing Association, Omaha, NE.

Vargas-Rodriguez, C. F., M. Engstrom, E. Azem, and B. J. Bradford. 2014. Effects of dietary amylase and sucrose on productivity of cows fed low-starch diets. J. Dairy Sci. 97:4464-4470. https://doi .org/10.3168/jds.2013-7845.

Weiss, W. P., W. Steinberg, and M. A. Engstrom. 2011. Milk production and nutrient digestibility by dairy cows when fed exogenous amylase with coarsely ground dry corn. J. Dairy Sci. 94:2492-2499. https://doi.org/10.3168/jds.2010-3766.

Yang, W. Z., K. A. Beauchemin, and L. M. Rode. 2000. A comparison of methods of adding fibrolytic enzymes to lactating cow diets. J. Dairy Sci. 83:2512-2520. https://doi.org/10.3168/jds.S0022 $-0302(00) 75143-5$. 